\section{Physiological performance of Coccoloba gigantifolia seeds subjected to desiccation and storage}

\author{
Sidney Alberto do Nascimento Ferreira ${ }^{1 *}$ (D) , Daniel Felipe de Oliveira Gentil ${ }^{2}$, \\ Carlos Alberto Cid Ferreira ${ }^{1}$
}

\begin{abstract}
Coccoloba gigantifolia is recently described species, with an area of restricted occurrence and threatened with extinction, whose great ornamental potential is due to the size of its leaves and the architecture of the plant. The objective of this study was to evaluate the viability of its seeds under different water contents and storage temperatures, through two experiments. The first one used a completely randomized design (CRD) with six treatments (drying periods: $0,1,2,3,4$ and 5 days) and four replications. The second experiment used a CRD in a 2 (storage temperatures: $8.0 \pm 1.2$ and $19.5 \pm 0.7^{\circ} \mathrm{C}$ ) $\times 3$ (storage periods: 1,2 and 4 months) factorial scheme, in addition to a control treatment (without storage), with four replications. The seeds have a recalcitrant behavior, as they are sensitive to desiccation, with a marked reduction in viability with moisture content below $19.5 \%$. Storage at temperatures of 8.0 and $19.5^{\circ} \mathrm{C}$ did not maintain the physiological quality of the seeds, with $25.2 \%$ water, and the largest losses were found at a temperature of $8.0^{\circ} \mathrm{C}$.
\end{abstract}

Index terms: desiccation tolerance, recalcitrant, ex situ conservation.

RESUMO: Coccoloba gigantifolia é uma espécie recentemente descrita, com área de ocorrência restrita e ameaçada de extinção, que apresenta grande potencial ornamental devido ao tamanho de suas folhas e à arquitetura da planta. Objetivou-se avaliar a viabilidade de suas sementes submetidas a diferentes teores de água e temperaturas de armazenamento, por meio de dois experimentos. No primeiro foi adotado o delineamento inteiramente casualizado (DIC), com seis tratamentos (períodos de secagem: 0, 1, 2, 3, 4 e 5 dias) e quatro repetições. No outro foi adotado o DIC, em esquema fatorial 2 (temperaturas de armazenamento: $8,0 \pm 1,2$ e $19,5 \pm 0,7^{\circ} \mathrm{C}$ ) $\times 3$ (períodos de armazenamento: 1,2 e 4 meses), além do tratamento controle (sem armazenamento), com quatro repetições. As sementes apresentam comportamento recalcitrante, pois são sensíveis ao dessecamento, com acentuada redução da viabilidade abaixo de 19,5\% de água. O armazenamento sob temperaturas de 8,0 e $19,5^{\circ} \mathrm{C}$ não manteve a qualidade fisiológica das sementes, com $25,2 \%$ de água, sendo as maiores perdas registradas na temperatura de $8,0^{\circ} \mathrm{C}$.

Termos para indexação: tolerância ao dessecamento, recalcitrante, conservação ex situ.
Journal of Seed Science, v.43, e202143020, 2021

http://dx.doi.org/10.1590/ 2317-1545v43250757
*Corresponding author E-mail:sanf@inpa.gov.br

Received: 4/6/2021

Accepted: 6/17/2021

\footnotetext{
${ }^{1}$ Coordenação de Biodiversidade, Instituto Nacional de Pesquisas da Amazônia, Caixa Postal 2223, 69080-971 - Manaus, AM, Brasil.

${ }^{2}$ Faculdade de Ciências Agrárias, Universidade Federal do Amazonas, 69077-000 - Manaus, AM, Brasil.
} 


\section{INTRODUCTION}

Coccoloba gigantifolia (Melo et al., 2019) is a recently described species of the Polygonaceae family, found only in the Rio Madeira basin, in the states of Amazonas and Rondônia, in the center and southwest of the Brazilian Amazon. It grows in open rainforests, secondary forests and scrub forests, at altitudes of 20-100 m, with flat relief and moist, sandy or clayey soils (Melo et al., 2019). It has an arboreal growth habit, with a straight trunk, reaching 10-15 m in height; the plants are polygamous-dioecious and, as a result, not all of them produce fruits and seeds; leaves are alternate, spiraled, petiolate, with elliptical blade of 0.6-2.5 x 0.5-1.4 m; anthocarps are globose, pubescent or puberulent, red, vinaceous or purple when mature, measuring 5-8 mm in length; the nucules are globose, smooth, slightly striated, with an acute or pyramidal apex; the seeds have ruminated endosperm (Melo et al., 2019).

The species has ornamental potential owing to the size of its leaves and the peculiar architecture of the plant. However, there is little information about its biology and virtually no information about its management. The scarce knowledge about the species is more worrying when taking into account the risk of extinction of the species in nature, owing to the restricted area of occurrence and deforestation for expansion of the agricultural frontier and for the construction of hydroelectric plants and highways (Melo et al., 2019). Faced with such a situation, in situ and ex situ conservation strategies should be adopted to avoid the extinction of this species.

In the long term, ex situ conservation of seeds can be performed in conventional germplasm banks at a temperature of -18 or $-20{ }^{\circ} \mathrm{C}$ and in cryogenic banks at $-156{ }^{\circ} \mathrm{C}$ (nitrogen vapor) or at $-196{ }^{\circ} \mathrm{C}$ (liquid nitrogen), depending on the level of desiccation tolerance (Salomão et al., 2015). The physiological response of seeds to desiccation varies among species, owing to the presence, absence or incomplete expression of a set of cellular mechanisms to protect and repair the resulting damage (Pammenter and Berjak, 1999). As a result of this variation, the following classification was created: orthodox, when seeds tolerate a reduction in moisture content to levels of 2 to $6 \%$, or even below; intermediate, when seeds tolerate desiccation up to a moisture content of 7 to $12 \%$; and, finally, recalcitrant, when seeds do not tolerate desiccation at moisture contents of 15 to $20 \%$ (Hong and Ellis, 1996). Although the use of orthodox, intermediate and recalcitrant categories is convenient, Pammenter and Berjak (1999) suggested the existence of a continuous gradient, from the most tolerant to the most sensitive to desiccation, which would better represent the seeds postharvest physiology.

Orthodox seeds can be dried and stored with low moisture content, enabling storage under controlled conditions of negative temperatures and low relative humidity. It is the absence of freezing water that allows orthodox seeds to be stored at below-zero temperatures (Berjak and Pammenter, 2013). Intermediate and recalcitrant seeds do not tolerate below-zero temperatures, and cold damage occurs in tropical intermediate seeds when exposed to temperatures below $10{ }^{\circ} \mathrm{C}$ and in tropical recalcitrant seeds at temperatures equal to or below $10-15{ }^{\circ} \mathrm{C}$, depending on the species (Hong and Ellis, 1996).

Knowledge of postharvest physiology allows establishing the most appropriate procedures for processing and storage of seeds, which are essential to maintain viability and vigor during in vivo conservation. In this sense, Hong and Ellis (1996) proposed a protocol to determine desiccation tolerance and seed storage behavior, through which seeds are classified on the basis of moisture content and survival rate.

As far as Coccoloba gigantifolia is concerned, it is still unknown whether its seeds tolerate desiccation up to $10-12 \%$ water or even up to $5 \%$ water, as well as whether they tolerate storage at positive temperatures below $10{ }^{\circ} \mathrm{C}$ or even at negative temperatures. As the species is propagated exclusively by seeds, this information represents basic knowledge that can be used to check the possibilities of storage in the short (a few days to a few months), medium (between one and ten years) or long term (over ten years) (Silva and Ferraz, 2015), aiming at in vivo conservation in germplasm-seed banks. Likewise, this information is useful for in vivo conservation in field collections, reintroduction into natural habitat for recovery of endangered populations and restoration of degraded ecosystems, which require the development of management technologies for harvesting, processing, storing and germinating seeds (Zamith and Scarano, 2004). Given the above, this study aimed to evaluate the viability of Coccoloba gigantifolia seeds under different moisture contents and storage temperatures. 


\section{MATERIAL AND METHODS}

\section{Origin and processing of seeds}

The anthocarps (fruit + perianth) of Coccoloba gigantifolia came from four bunches of a plant grown at the National Institute of Amazonian Research, Campus III ( $3^{\circ} 5^{\prime} 33.12^{\prime \prime} \mathrm{S}$; 59 59' 35.36" W), in Manaus, Amazonas. The region's climate is classified as Af, with an average annual temperature of $26.7^{\circ} \mathrm{C}$ and an average annual rainfall of $2,420 \mathrm{~mm}$ (Alvares et al., 2013). After the anthocarps were removed from the bunches, they were mixed and selected by the color of the perianth - from those that were $50 \%$ red to completely purple ones, while the others were discarded.

The nucules (pericarp + seed) were extracted manually by rubbing the anthocarps in running water. Then, the nucules were treated with sodium hypochlorite $(0.5 \%)$ for fifteen minutes, and those that floated in the water were discarded. Afterwards, they were rinsed and kept in a perforated plastic bag, until the next morning. Before the beginning of the experiments, the nucules remained in a single layer inside plastic trays, for one hour, in a laboratory environment $\left(23.2 \pm 0.7^{\circ} \mathrm{C}\right.$ and $\mathrm{RH}$ of $\left.60.8 \pm 3.9 \%\right)$ for superficial drying of the pericarp. Based on this material, henceforth considering the nucules as a seed unit, two experiments were installed, as follows:

\section{Desiccation tolerance}

The experimental design was completely randomized, with six treatments (desiccation periods) and four replications of 25 seeds each. The methodology was adapted from the protocol by Hong and Ellis (1996). Thus, the seeds were divided into lots of 125 units each, placed in germination boxes $(11 \times 11 \times 3.5 \mathrm{~cm})$, on a stainless-steel screen. At the bottom of each box, $90 \mathrm{~g}$ of dehydrated silica gel was placed and changed daily. The seeds remained in this condition for periods of $0,1,2,3,4$ and 5 days, which resulted in lots with different moisture contents, determined by the oven method at $105 \pm 3{ }^{\circ} \mathrm{C}$, for 24 hours (Brasil, 2009), using two replicates of ten seeds per lot.

Subsequently, the seeds were sown in drained plastic boxes $(26 \times 17 \times 6 \mathrm{~cm})$, containing medium textured vermiculite substrate, and kept in a greenhouse (mean minimum temperature of $26.1 \pm 0.4{ }^{\circ} \mathrm{C}$ and maximum temperature of $37 \pm 2.6^{\circ} \mathrm{C}$ ). Irrigation was performed whenever necessary, trying to keep the substrate moist and without waterlogging.

Seedling emergence was evaluated every five days for 120 days, and seedlings with elongation of the hypocotyl above the substrate (epigeal germination) were considered to have emerged. Based on these data, in percentage, emergence speed index (ESI) and mean emergence time (MET) were calculated, according to Ranal and Santana (2006).

As the treatments were quantitative $(0,1,2,3,4$ and 5 days of drying), regression analysis was performed for the study variables, accepting the highest level of significant adjustment, up to the third degree. Analyses were performed using the software ASSISTAT version 7.7 (Silva and Azevedo, 2016).

\section{Viability conservation}

The experiment used a completely randomized design in a 2 (storage temperatures) $\times 3$ (storage periods) factorial scheme, in addition to a control treatment (no storage), with four replications, each containing 25 seeds. Thus, seed lots with a moisture content of $25.2 \%$ (achieved after a day of drying on silica gel, as described above) were packed in double packaging (plastic bag inside a plastic bottle, sealed separately) and stored at two temperatures $\left[8.0 \pm 1.2^{\circ} \mathrm{C}\right.$ (refrigerator) and $19.5 \pm 0.7^{\circ} \mathrm{C}$ (refrigerated chamber)], for different periods (1, 2 and 4 months).

After each storage period, sowing was performed and seedling emergence and other vigor variables were evaluated, in the same way as in the previous experiment. The percentage values were transformed into arcsine $\sqrt{ } x / 100$, while the others were transformed into $V x$, when there was a need to normalize them. The results were presented and discussed with the averages of the original data, without transformation. Analyses of variance and comparison of data means were performed using the software ASSISTAT version 7.7 (Silva and Azevedo, 2016). 


\section{RESULTS AND DISCUSSION}

\section{Desiccation tolerance}

The different drying periods provided different moisture contents in the Coccoloba gigantifolia seeds (Figure 1). Before drying, the newly processed seeds had a high moisture content (49.3\%), which is common in recalcitrant seeds, whose moisture content is high at the end of maturation and/or dispersion (Mayrinck et al., 2016). According to Hong and Ellis (1996), dispersed or harvested seeds with a moisture content equal to or less than $20 \%$ will probably show orthodox behavior, although no generalization can be made if the moisture content is between 25 and $55 \%$.

After a day of drying, the Coccoloba gigantifolia seeds showed a marked reduction in moisture content, with a loss of about $51 \%$ of the initial moisture content, with moisture content reaching $25.2 \%$. As drying continued, water losses occurred in a smaller proportion compared to the immediately previous period, with the seeds reaching the moisture contents of 19.5, 11.4, 8.8 and $6.8 \%$, after 2, 3, 4 and 5 days, respectively (Figure 1). Possibly, moisture content between 49.3 and $25.2 \%$ corresponds to capillary or free water, therefore presenting faster evaporation; while the remaining water is likely bound to increasingly hydrophilic molecular sites, resulting in a slower drying rate (Bewley et al., 2013).

In response to the desiccation periods, emergence and ESI were fitted to a cubic equation while MET, to a quadratic equation (Table 1 and Figure 2). In newly-processed seeds, emergence (35\%) was lower than the one achieved in seeds after one day of drying (58\%). This is probably due to primary dormancy, which occurs during seed maturation,

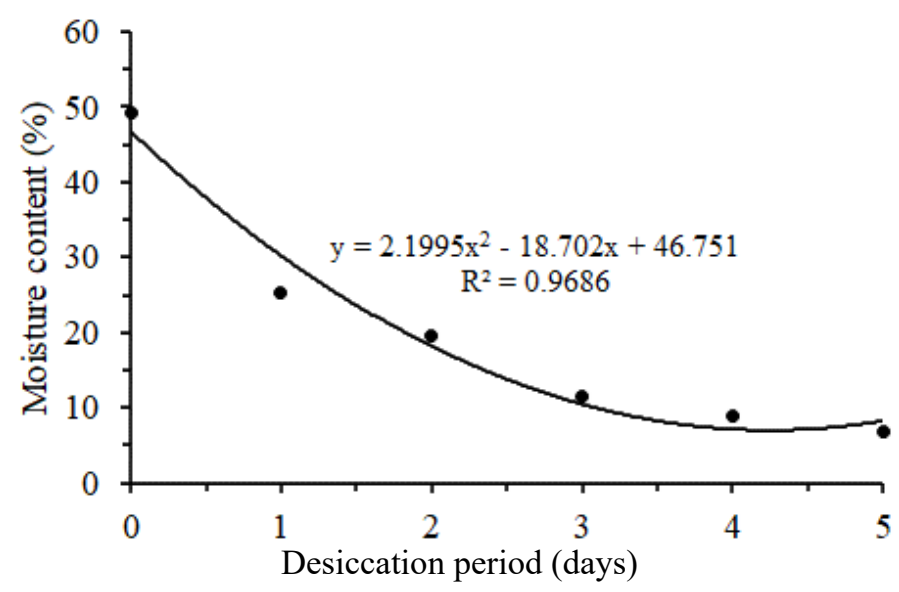

Figure 1. Moisture content of Coccoloba gigantifolia seeds after different desiccation periods.

Table 1. Summary of regression analysis of variance referring to emergence, emergence speed index (ESI) and mean emergence time (MET) of Coccoloba gigantifolia seeds under different desiccation periods.

\begin{tabular}{ccccc}
\hline \multirow{2}{*}{ Source of variation } & DF & \multicolumn{3}{c}{ Mean square } \\
\cline { 3 - 5 } & & Emergence & ESI & MET \\
\hline Linear regression & 1 & $8,558.23^{* *}$ & $2.87^{* *}$ & $164.67^{* *}$ \\
Quadratic regression & 1 & $438.86 \mathrm{~ns}$ & $0.26^{*}$ & $117.37^{*}$ \\
Cubic regression & 1 & $3,882.76^{* *}$ & $1.60^{* *}$ & $26.49 \mathrm{~ns}$ \\
Residual & 18 & 103.33 & 0.04 & 15.49 \\
\hline CV (\%) & & 41.49 & 42.68 & 6.82 \\
\hline
\end{tabular}

* and **: significant at the level of 0.05 and 0.01 (p), by the F-test, respectively. ns: non-significant at the 0.05 (p) level by the $F$ test. DF: degree of freedom. 
preceding the dispersal of fruits and/or seeds (Bewley et al., 2013). Baskin and Baskin (2014) reported that germination studies should be carried out soon after seed harvesting, followed by a short drying period, which may favor the response to the germination test and/or dormancy breaking treatments.

After one day of drying, emergence decreased progressively until it was null, between 3 and 4 days of drying, when it reached the estimated moisture content of $8.0 \%$ (Figure 2A). ESI had a similar behavior to that of emergence; it was initially lower, rising in the period of one day of drying, after which it also decreased (Figure 2B).
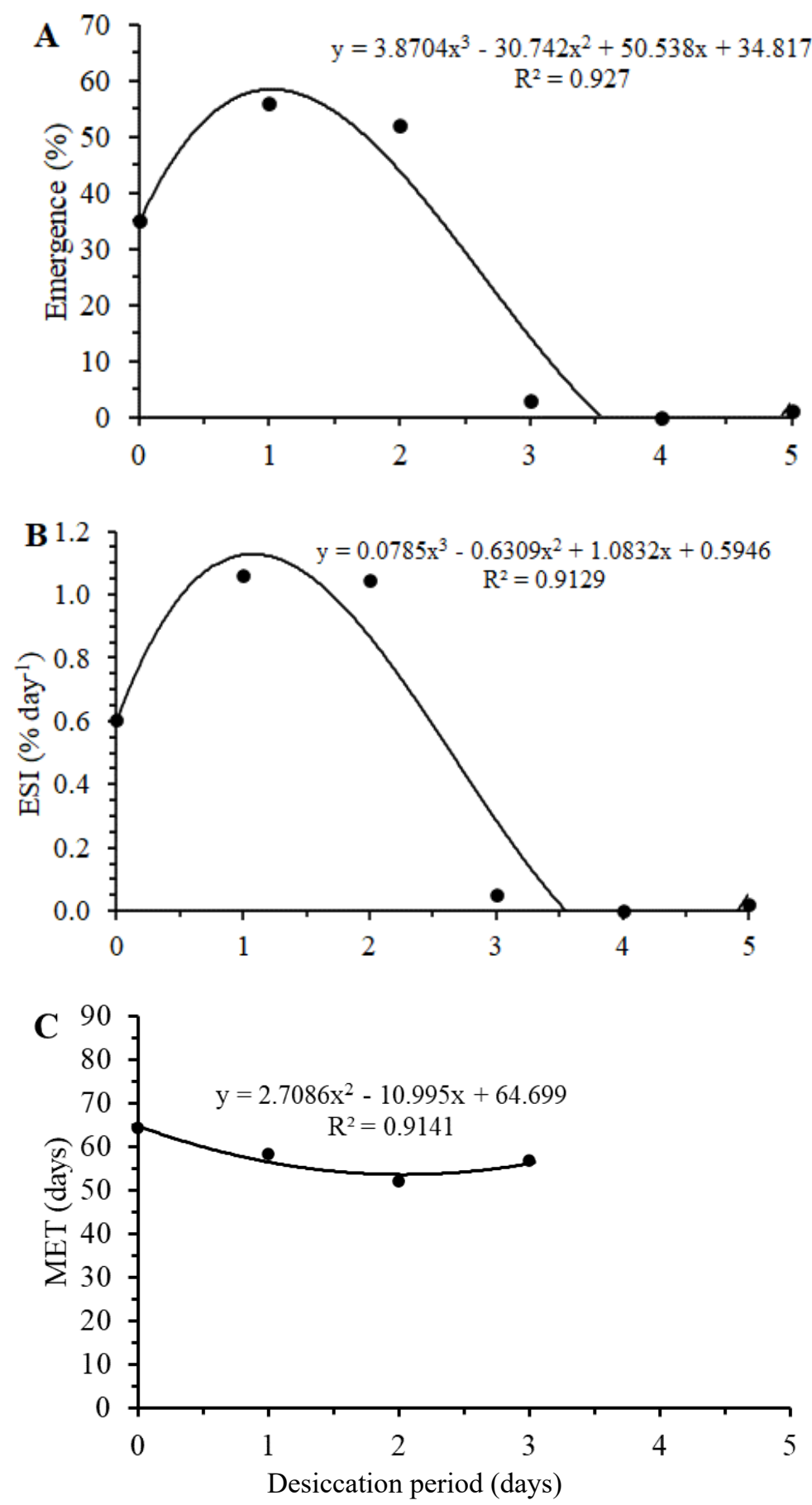

Figure 2. Emergence (A), emergence speed index (ESI) (B) and mean emergence time (MET) (C), referring to Coccoloba gigantifolia seeds under different periods of desiccation. 
Regardless of the regression adjustment, it was found that after two days of drying (19.5\% of moisture content), emergence was still satisfactory (52\%), taking into account that maximum value was $56 \%$ in seeds with moisture content of $25.2 \%$ (Figures 1 and 2A). Thus, based on the classification adopted by Zamith and Scarano (2004), the germination percentage of Coccoloba gigantifolia seeds can be considered to be average $(40 \%<x<80 \%)$, a fact that has been found in species of the same genus, as in Coccoloba arborescens with 43\% germination (Zamith and Scarano, 2004), and C. barbadensis with $47.7 \%$ (Soriano et al., 2011) to 69\% germination (Zamora-Cornelio et al., 2010). Other species of the genus, however, have shown high germination, such as C. diversifolia (82\%) and C. microstachya (98\%) (Francis and Rodriguez, 1993). Thus, new studies on the germination process of Coccoloba gigantifolia seeds need to be conducted to discover the causes of the low initial percentage. As mentioned above, this may have been due to dormancy; in addition, there may have been incipient embryos and/or malformed seeds. In this sense, it is worth noting that, during processing, some apparently empty seeds floated in the water (data not quantified) and were discarded.

The highest MET (65 days) was found in seeds with the highest moisture content (Figure 2C). With increased desiccation time and, consequently, reduction in moisture content, MET was reduced until reaching the lowest value (54 days) after two days of drying (19.5\% moisture). In seeds of $C$. arborescens, whose germination is considered to be slow, MET was 46.6 days, with a range between 30 and 61 days (Zamith and Scarano, 2004). In C. barbadensis, the beginning of seed germination occurred at six days and the last seed germinated at 51 days after sowing (ZamoraCornelio et al., 2010). Given the above, considering the slow germination of Coccoloba gigantifolia seeds, the need for pre-germinative treatments needs to be investigated.

Coccoloba gigantifolia seeds showed a marked loss of viability when desiccated to moisture contents below $19.5 \%$, and the lethal level corresponded to the estimated moisture content of $8 \%$ (Figure 2A), after which no germination occurred. Therefore, following the protocol of Hong and Ellis (1996), as most of the seeds died when dried to 10-12\% moisture, they showed sensitivity to desiccation and, therefore, can be considered as recalcitrant. Delgado and Barbedo (2012) suggested that water potential is more reliable than seed moisture content, and that differences in desiccation tolerance between species of Eugenia (Myrtaceae) may be due to the degree of maturity during dispersal, which may also mean that the seeds were dispersed at a maturity stage similar to the one found in immature orthodox seeds.

The proportion of species with seeds that are sensitive to desiccation decreases as the habitat becomes drier and possibly also cooler (Tweddle et al., 2003). Therefore, seed sensitivity to desiccation is more common in species from moist habitats, such as the one where Coccoloba gigantifolia occurs naturally (Melo et al., 2019).

Sensitivity to desiccation is also more frequent in species whose seeds do not have dispersal dormancy, but not all species with dormant seeds are necessarily desiccation-tolerant (Tweddle et al., 2003). One species that has this rare combination is Garcinia gardneriana (Clusiaceae), whose seeds are dispersed with $51.7 \%$ moisture and lose viability when desiccated at moisture contents below 20.0\% (Viana et al., 2020). This may also be the case for Coccoloba gigantifolia, although the benefits of this ecological strategy need to be clarified with detailed information on fruiting phenology, seed dispersal and specific habitat characteristics.

The first challenge for the conservation of recalcitrant seeds is to determine their response to desiccation. However, in addition to evaluating the effect of desiccation on seed viability, seed longevity response to storage environments is another practical way to determine the pattern of seed behavior (Hong and Ellis, 1996).

\section{Viability conservation}

Emergence, ESI and MET showed a significant interaction effect between the factors "storage temperature" and "storage period" (Table 2). For these variables, with the exception of MET, the control treatment (no storage) differed significantly from the other treatments, indicating that seed quality was not maintained during storage. However, the levels of the "storage temperature" factor behaved differently from the levels of the "storage period" factor (Table 3). Most of the time, although in some cases there was no significance, the temperature of $19.5 \pm 0.7^{\circ} \mathrm{C}$ (chamber) provided the best results compared to $8.0 \pm 1.2^{\circ} \mathrm{C}$ (refrigerator), which shows greater seed sensitivity to lower temperatures. 
Table 2. Summary of the analysis of variance regarding emergence, emergence speed index (ESI) and mean emergence time (MET) of Coccoloba gigantifolia seeds stored in different environments for different periods.

\begin{tabular}{ccccc}
\hline & DF & \multicolumn{3}{c}{ Mean square } \\
\cline { 3 - 5 } Source of variation & 1 & Emergence & ESI & MET \\
\hline Temperature (T) & 2 & $497.34^{*}$ & $0.141^{* *}$ & $545.34^{* *}$ \\
Period (P) & 2 & $339.40^{*}$ & $0.100^{* *}$ & $204.00^{*}$ \\
T x P & $276.98^{*}$ & $0.097^{* *}$ & $586.16^{* *}$ \\
Control x Factorial Design & 1 & $2401.44^{* *}$ & $0.358^{* *}$ & $120.00 \mathrm{~ns}$ \\
Residual & 21 & 66.73 & 0.011 & 54.52 \\
\hline CV (\%) & 30.98 & 11.00 & 13.91 \\
\hline Average Control (\%, \% day ${ }^{-1}$ and day) & $56 \mathrm{a}$ & $1.060 \mathrm{a}$ & $58.1 \mathrm{a}$ \\
\hline Factorial Average $\left(\%, \%\right.$ day $^{-1}$ and day) & $17 \mathrm{~b}$ & $0.379 \mathrm{~b}$ & $52.2 \mathrm{a}$ \\
\hline
\end{tabular}

* and $* *$ : significant at the level of 0.05 and $0.01(p)$, by the F-test, respectively.

ns: non-significant at the $0.05(p)$ level by the F-test.

DF: degree of freedom.

When comparing the means between Control and Factorial, for each variable (emergence, ESI and MET), those with the same letter do not differ significantly from each other by Tukey's test at a level of $0.05(p)$.

Table 3. Emergence, emergence speed index and mean emergence time for Coccoloba gigantifolia seeds stored at different temperatures for different periods.

\begin{tabular}{|c|c|c|c|}
\hline \multirow{2}{*}{ Storage temperature } & \multicolumn{3}{|c|}{ Storage period (month) } \\
\hline & 1 & 2 & 4 \\
\hline & \multicolumn{3}{|c|}{ Emergence (\%) } \\
\hline $8.0 \pm 1.2^{\circ} \mathrm{C}$ (refrigerator) & $17 \mathrm{aA}$ & $13 \mathrm{aB}$ & $4 \mathrm{aA}$ \\
\hline \multirow[t]{2}{*}{$19.5 \pm 0.7^{\circ} \mathrm{C}$ (chamber) } & $12 \mathrm{bA}$ & $39 \mathrm{aA}$ & $15 \mathrm{bA}$ \\
\hline & \multicolumn{3}{|c|}{ Emergence speed index $\left(\%\right.$ day $\left.^{-1}\right)$} \\
\hline $8.0 \pm 1.2^{\circ} \mathrm{C}$ (refrigerator) & $0.346 \mathrm{aA}$ & $0.271 \mathrm{aB}$ & $0.067 \mathrm{aA}$ \\
\hline \multirow[t]{2}{*}{$19.5 \pm 0.7^{\circ} \mathrm{C}$ (chamber) } & $0.209 \mathrm{bA}$ & $1.015 \mathrm{aA}$ & $0.364 \mathrm{bA}$ \\
\hline & \multicolumn{3}{|c|}{ Mean emergence time (days) } \\
\hline $8.0 \pm 1.2^{\circ} \mathrm{C}$ (refrigerator) & $51.4 \mathrm{bA}$ & $52.9 \mathrm{bA}$ & $66.7 \mathrm{aA}$ \\
\hline $19.5 \pm 0.7^{\circ} \mathrm{C}$ (chamber) & $60.4 \mathrm{aA}$ & 40.1 bB & $41.9 \mathrm{bB}$ \\
\hline
\end{tabular}

Means followed by the same uppercase letter in the column and the same lowercase letter in the row, within the levels of each factor, do not differ significantly from each other by Tukey's test at the 0.05 (p) level of probability.

Unlike the findings for Coccoloba gigantifolia seeds, the seeds of $C$. uvifera maintained viability after fifteen months of storage at room temperature $\left(27.2 \pm 1.8^{\circ} \mathrm{C}\right)$ and in the refrigerator $\left(4.0 \pm 1.5^{\circ} \mathrm{C}\right)$, reaching $95 \%$ and $75 \%$ germination, respectively (Vargas-Simón and Pire, 2010).

According to Hong and Ellis (1996), desiccation tolerance can be characteristic of a particular botanical family or genus. However, differences in physiological behavior may occur between families, genera and species. In fact, although species of the same genus have related evolutionary trajectories, any difference in ecophysiological responses may indicate possible adaptations to the habitat occupied by each one, rather than phylogenetic effects (Tweddle et al., 2003). Furthermore, different physiological behaviors of seeds within the same species may be related to the 
genotype, the environmental conditions in regions or production seasons, differences in maturation and drying of the seeds (Barbedo, 2018).

In the first experiment, which was an adaptation of the protocol proposed by Hong and Ellis (1996), it was found that Coccoloba gigantifolia seeds are sensitive to desiccation. In the second experiment, the seeds showed low tolerance to refrigeration, which shows that the storage of desiccation-sensitive seeds poses a challenge to ex situ conservation.

According to Umarani et al. (2015), the most practical way to extend the storage period of desiccation-sensitive seeds is to store them at the lowest possible temperature, at which cell damage can be reduced while cold or freezing injuries can be avoided. Thus, studies with Coccoloba gigantifolia should be continued, seeking to identify the best combination between seed moisture content and storage temperature, even if it is meant for conservation for a short period of time.

\section{CONCLUSIONS}

Coccoloba gigantifolia seeds show a recalcitrant behavior, as they are sensitive to desiccation, with a marked reduction in viability when dried at moisture levels below $19.5 \%$. Storage at temperatures of 8.0 and $19.5^{\circ} \mathrm{C}$ was not favorable to maintaining seed quality with $25.2 \%$ of moisture.

\section{REFERENCES}

ALVARES, C.A.; STAPE, J.L.; SENTELHAS, P.C.; GONÇALVES, J.L.M.; SPAROVEK, G. Köppen's climate classification map for Brasil. Meteorologische Zeitschrift, v.22, n.6, p.711-728, 2013. DOI: 10.1127/0941-2948/2013/0507

BARBEDO, C.J. A new approach towards the so-called recalcitrant seeds. Journal of Seed Science, v.40, n.3, p.221-236, 2018. DOI: 10.1590/2317-1545v40n3207201

BASKIN, C.C.; BASKIN, J.M. Seeds: ecology, biogeography, and evolution of dormancy and germination. $2^{\text {nd }}$ edition. San Diego: Elsevier, 2014. 1586p.

BERJAK, P.A.; PAMMENTER, N.W. Implications of the lack of desiccation tolerance in recalcitrant seeds. Frontiers in Plant Science, v.4, a.478, p.1-9, 2013. DOI: 10.3389/fpls.2013.00478

BEWLEY, J.D.; BRADFORD, K.J.; HILHORST, H.W.M.; NONOGAKI H. Seeds: physiology of development, germination and dormancy. $3^{\text {rd }}$ edition. New York: Springer, 2013. 392p. DOI: 10.1007/978-1-4614-4693-4

BRASIL. Ministério da Agricultura, Pecuária e Abastecimento. Regras para análise de sementes. Ministério da Agricultura, Pecuária e Abastecimento. Secretaria de Defesa Agropecuária. Brasília: MAPA/ACS, 2009, 399p. https://www.gov.br/agricultura/pt-br/ assuntos/insumos-agropecuarios/arquivos-publicacoes-insumos/2946_regras_analise_sementes.pdf

DELGADO, L.F.; BARBEDO, C.J. Water potential and viability of seeds of Eugenia (Myrtaceae), a tropical tree species, based upon different levels of drying. Brazilian Archives of Biology and Technology, v.55, n.4, p.583-590, 2012. https://www.scielo.br/pdf/babt/ v55n4/a14v55n4.pdf

FRANCIS, J.K.; RODRIGUEZ, A. Seeds of Puerto Rican trees and shrubs: second installment. Research Note SO-374. U.S. Department of Agriculture, Forest Service, Southern Forest Experiment Station, New Orleans, LA. 5p., 1993. https://www.srs.fs.usda.gov/pubs/ rn/rn_so374.pdf

HONG, T.D.; ELLIS, R.H. A protocol to determine seed storage behaviour. Rome: IPGRI, 1996. 62p. https://cropgenebank.sgrp.cgiar. org/images/file/learning_space/technicalbulletin1.pdf

MAYRINCK, R.C.; VAZ, T.A.A.; DAVIDE, A.C. Physiological classification of forest seeds regarding the desiccation tolerance and storage behaviour. Cerne, v.22, n.1, p.85-92, 2016. DOI: 10.1590/01047760201622012064

MELO, E.; CID FERREIRA, C.A.; GRIBEL, R. A new species of Coccoloba P. Browne (Polygonaceae) from the Brazilian Amazon with exceptionally large leaves. Acta Amazonica, v.49, n.4, p.324-329, 2019. DOI: 10.1590/1809-4392201804771 
PAMMENTER, N.W.; BERJAK, P. A review of recalcitrant seed physiology in relation to desiccation tolerance mechanisms. Seed Science Research, v.9, n.1, p.13-37, 1999. DOI: 10.1017/S0960258599000033

RANAL, M.A.; SANTANA, D.G. How and why to measure the germination process? Revista Brasileira de Botânica, v.29, n.1, p.1-11, 2006. DOI: 10.1590/S0100-84042006000100002

SALOMÃO, A.N.; SANTOS, I.R.I.; WALTER, B.M.T. Coleta e conservação de recursos genéticos ex situ: sementes de espécies florestais nativas. In: PIÑA-RODRIGUES, F.C.M; FIGLIOLIA, M.B.; SILVA, A. (ed.). Sementes florestais tropicais: da ecologia à produção. Londrina: ABRATES, 2015. p.167-178.

SILVA, A.; FERRAZ, I.D.K. Armazenamento de sementes. In: PIÑA-RODRIGUES, F.C.M.; FIGLIOLIA, M.B.; SILVA, A. Sementes florestais tropicais: da ecologia à produção. Londrina: ABRATES, 2015. p.219-242.

SILVA, F.A.S.; AZEVEDO, C.A.V. The Assistat Software Version 7.7 and its use in the analysis of experimental data. African Journal of Agricultural, v.11, p.3733-3740, 2016. DOI: 10.5897/AJAR2016.11522

SORIANO, D.; OROZCO-SEGOVIA, A.; MÁRQUEZ-GUZMÁN, J.; KITAJIMA, K.; GAMBOA-DE-BUEN, A.; HUANTE, P. Seed reserve composition in 19 tree species of a tropical deciduous forest in Mexico and its relationship to seed germination and seedling growth. Annals of Botany, v.107, n.6, p.939-951, 2011. DOI: 10.1093/aob/mcr041

TWEDDLE, J.C.; DICKIE, J.B.; BASKIN, C.C.; BASKIN, J.M. Ecological aspects of seed desiccation sensitivity. Journal of Ecology, v.91, p.294-304, 2003. https://besjournals.onlinelibrary.wiley.com/doi/epdf/10.1046/j.1365-2745.2003.00760.x

UMARANI, R.; AADHAVAN, E.K.; FAISAL, M.M. Understanding poor storage potential of recalcitrant seeds. Current Science, v.108, n.11, p.2023-2034, 2015. https://wwwops.currentscience.ac.in/Volumes/108/11/2023.pdf

VARGAS-SIMÓN, G.; PIRE, R. Efecto de dos condiciones de almacenamiento em la germinación de semillas de uva de playa (Coccoloba uvifera (L.) Jacq.). Revista de la Facultad de Agronomia, v.27, n.4, p.559-573, 2010. https://www.revfacagronluz.org.ve/ PDF/octubre_diciembre2010/v27n4a20104.pdf

VIANA, W.G.; LANDO, A.P.; SILVA, R.A.; COSTA, C.D.; VIEIRA, P.H.M.; STEINER, N. Physiological performance of Garcinia gardneriana (Planch. \& Triana) Zappi: a species with recalcitrant and dormant seeds. Journal of Seed Science, v.42, e202042001, 2020. DOI: $10.1590 / 2317-1545 v 42222357$

ZAMITH, L.R.; SCARANO, F.R. Produção de mudas de espécies das restingas do município do Rio de Janeiro, RJ, Brasil. Acta Botanica Brasilica, v.18, n.1, p.161-176, 2004. DOI: 10.1590/S0102-33062004000100014

ZAMORA-CORNELIO, L.F.; OCHOA-GAONA, S.; SIMÓN, G.V.; ALBORES, J.C.; JONG, B.H.J. Germinación de semillas y clave para la identificación de plántulas de seis especies arbóreas nativas de humedales del sureste de México. Revista de Biologia Tropical, v.58, n.2, p.717-732, 2010. DOI: 10.15517/rbt.v58i2.5241 use, distribution, and reproduction in any medium, provided the original work is properly cited. 